\title{
Nursing knowledge and practices regarding subcutaneous fluid administration
}

\author{
Conhecimentos e práticas da enfermagem na administração de fluidos por via subcutânea \\ Conocimientos y prácticas de enfermería en la administración de fluidos por vía subcutánea
}

\section{Nathália Silva Gomes', Andrea Mara Bernardes da Silva", Luana Barbosa Zago', Érica Carneiro de Lima e Silva"I', Elizabeth Barichello'}

' Universidade Federal do Triângulo Mineiro, Strictu Sensu Postgraduate Program in Health Care. Uberaba, Minas Gerais, Brazil. "Universidade Federal de São Paulo, Ribeirão Preto College of Nursing,

Postgraduate Program in Fundamental Nursing. Ribeirão Preto, São Paulo, Brazil.

"' Health Foundation of the City of Uberlândia, Program "Melhor em Casa". Uberlândia, Minas Gerais, Brazil.

How to cite this article:

Gomes NS, Silva AMB, Zago LB, Lima e Silva EC, Barichello E. Nursing Knowledge and Practices Regarding Subcutaneous Fluid Administration. Rev Bras Enferm [Internet]. 2017;70(5):1096-105. [Thematic Edition "Good practices and fundamentals of Nursing work in the construction of a democratic society"] DOI: http://dx.doi.org/10.1590/0034-7167-2016-0424

Approval: 01-22-2017

\begin{abstract}
Objective: To describe the evidence in the literature regarding the knowledge and practices of the nursing team about subcutaneous administration of drugs and fluids in adults. Method: Integrative review of the literature using the descriptors "nursing", "hypodermoclysis", "drug administration routes", "adult health," and "knowledge," in English, Spanish, and Portuguese, with no publication deadline. Of the 569 articles found, eight made up the sample. Results: A predominance of international journals (75\%) with more than five years of publication $(62.5 \%)$. The analysis of the methodological characteristics showed a predominance of literature reviews (25\%), quantitative studies $(62.5 \%)$, cross-sectional studies (50\%), and nonexperimental studies (50\%). Conclusion: Although it is an old technique with proven efficacy, hypodermoclysis is still little used, a puzzling fact due to its advantages and indications for any age.
\end{abstract}

Descriptors: Nursing; Hypodermoclysis; Drug Administration Routes; Knowledge; Practical Nursing.

\section{RESUMO}

Objetivo: descrever as evidências, na literatura, sobre os conhecimentos e as práticas da equipe de enfermagem na administração de medicamentos e de fluidos por via subcutânea no adulto. Método: revisão integrativa da literatura utilizando os descritores enfermagem, hipodermóclise, vias de administração de medicamentos, saúde do adulto e conhecimento; nos idiomas inglês, espanhol e português, sem data limite de publicação. Dos 569 artigos encontrados, oito compuseram a amostra. Resultados: predomínio de revistas internacionais (75\%) e com mais de cinco anos de publicação (62,5\%). Ao analisarem-se as características metodológicas, predominaram: revisões de literatura (25\%), estudos quantitativos (62,5\%), estudos transversais (50\%) e nãoexperimentais (50\%). Conclusão: apesar de se tratar de uma técnica antiga com eficácia comprovada, a hipodermóclise ainda é pouco utilizada, fato incoerente pelas suas vantagens e suas indicações para qualquer idade.

Descritores: Enfermagem; Hipodermóclise; Vias de Administração de Medicamentos; Conhecimento; Enfermagem Prática.

\section{RESUMEN}

Objetivo: Describir las evidencias, en la literatura, acerca de los conocimientos y prácticas del equipo de enfermería sobre administración de medicamentos y fluidos por vía subcutánea en adultos. Método: Revisión integrativa de la literatura, utilizando los descriptores: enfermería, hipodermoclisis, vías de administración de medicamentos, salud del adulto y conocimiento; en idiomas inglés, español y portugués, sin fecha límite de publicación. Fueron encontrados 569 artículos, de los cuales 8 integraron la muestra. Resultados: Predominio de revistas internacionales (75\%), y con más de cinco años de publicación (62,5\%). Al analizarse las características metodológicas, predominaron: revisiones de literatura (25\%), estudios cuantitativos (62,5\%), estudios 
transversales (50\%) y no experimentales (50\%). Conclusión: A pesar de tratarse de una técnica antigua de comprobada eficacia, la hipodermoclisis es aún poco utilizada, hecho inexplicable, dadas sus ventajas e indicaciones para cualquier edad.

Descriptores: Enfermería; Hipodermoclisis; Vías de Administración de Medicamentos; Conocimiento; Enfermería Práctica.

\section{CORRESPONDING AUTHORＥlizabeth BarichelloＥ-mail: lizabarichello@hotmail.com}

\section{INTRODUCTION}

The terms hypodermoclysis or subcutaneous therapy refer to the subcutaneous infusion of isotonic fluids and/or drugs ${ }^{(1)}$. In 1903, this technique was widely used in the hospital environment in the treatment of dehydrated patients, highlighting the benefits and the possibility of avoiding the difficulties, inconvenience, and impracticability of the technique of intravenous perfusion and other alternatives ${ }^{(2)}$. Moreover, its applicability has also been recognized in pediatric patients ${ }^{(3)}$. However, due to the iatrogenics related to the quality of puncture and solutions administered, as well as to technological advances, hypodermoclysis was abandoned in the second half of the $19^{\text {th }}$ century; by 1950 , serious complications related to water overload and circulatory shock after large-volume SC infusion were observed ${ }^{(4)}$.

At the end of 1960, with the advent of palliative care in England, hypodermoclysis was reassessed as a safe route of drug administration $^{(2,5)}$. However, it was in the 1980s that its use returned to clinical practice, especially in patients undergoing palliative care and in the elderly. The technical question related to the restriction of volumes, drugs, infusion time, and nursing care was emphasized, with its advantages and disadvantages, indications, contraindications and limitations being detailed ${ }^{(6)}$.

As far as physiological principles are concerned, it is known that the skin is responsible for maintaining body integrity, protecting against external aggressions, absorbing and excreting liquids, regulating temperature, and metabolizing vitamins (such as vitamin D). It consists of the epidermis, dermis, and hypodermis ${ }^{(1)}$.

The hypodermis is also known as subcutaneous tissue (SC) and has as its main function the nutrient storage of energy reserves, working as a thermal insulating agent and mechanical protector of the organism against external pressures and trauma. SC is composed of dense connections and adipose tissue, harboring blood vessels, lymphatics, glands, and nerves ${ }^{(1-2)}$. It also has the characteristic of being a loose tissue, which allows the skin to be moved ${ }^{(7)}$. This, combined with the fact that it has blood vessels, makes it a favorable route for the administration of fluids and/or drugs, because these are absorbed and transported to the macrocirculation ${ }^{(1)}$.

The SC tissue vasculature is compared to that of the intramuscular (IM) tissue, and the absorption of large volumes of solutions administered through hypodermoclysis is mediated by simple diffusion to the blood capillaries and lymphatic vessels through the action of hydrostatic and osmotic forces that allow the solution to reach the intravascular space ${ }^{(2,5)}$.

Plasma levels are similar to those achieved with IM, oral, rectal, sublingual, and intravenous (IV) administration. The drug doses are the same as those used in IV, but the onset of action is generally similar to that of the oral route, that is, from 15 to 30 minutes $^{(5)}$. The vascularization of the SC tissue accounts for around $6 \%$ of the cardiac output and reaches lower serum concentrations, but with a longer action time, and higher than that of the IV and IM routes. As a result, pre-systemic clearance by the liver is avoided, resulting in a stable drug serum concentration, preventing undesirable side effects due to plasma peaks ${ }^{(8)}$.

SC therapy encompasses not only the replacement of fluids, but also medicines that were prescribed for this route, such as antimicrobials and analgesics, among others. Some of these medicinal products do not present a description in the package insert of the possibility of being administered by this technique; thus, when prescribed, their use is considered as off-label ${ }^{(9)}$.

Therefore, although it is an old technique, SC therapy is still little known and used. Thus, it is necessary that it is disseminated in order to increase theoretical and practical knowledge, as well as to raise scientific production in order to present the available evidence.

\section{OBJECTIVE}

To describe the available evidence, in the literature, regarding nursing teams' knowledge and practices when administering drugs and fluids subcutaneously in adults.

\section{METHOD}

\section{Ethical aspects}

Regarding the research's ethical aspects, due to its scientific profile the integrative review (IR) is highlighted, because it does not require the submission of the study to a Research Ethics Committee.

\section{Design}

This is an integrative review. This method includes the analysis of studies that provide support for decision-making and improvement of clinical practice, enables the synthesis of multiple published studies, and allows general conclusions regarding a certain area of knowledge. The synthesis of the surveys included in the review reduces uncertainties about practical recommendations, allows generalizations about the phenomenon from the available information, and facilitates decision-making regarding interventions that could result in more effective and cost-effective care ${ }^{(10)}$.

\section{Population, and inclusion and exclusion criteria}

To elaborate this IR, the following steps were taken: establishing the hypothesis (hypodermoclysis remains underused due to the lack of knowledge by health professionals); objectives of IR; establishment of articles' inclusion and exclusion criteria (sample selection); definition of the information to be extracted from the selected articles based on the objective of the study; analysis of results; and discussion and presentation of results. The last stage consisted of the presentation of the review ${ }^{(11)}$. 
To guide the IR, the following guiding question was formulated: What is the knowledge and practice of the nursing team in medication and fluid administration via hypodermoclysis in the adult patient?

For selecting the articles, the following databases were used: the Cumulative Index to Nursing and Allied Health Literature (CINAHL); the Medical Literature Analysis and Retrieval System on-line (MEDLINE); the Latin American and Caribbean Center on Health Sciences Information (LILACS); Science Direct; and Web of Science. These databases were selected because they are internationally recognized and include well-known journals in the health area.

Inclusion criteria were: articles published in Portuguese, English, or Spanish; with abstract available; with no time limit; through the combination of the following descriptors: nursing and hypodermoclysis; drug administration routes and hypodermoclysis; adult health and hypodermoclysis; knowledge and hypodermoclysis. It should be noted that the open period of time was necessary due to the difficulty to find articles related to the subject when a previous bibliographic survey of only the last 10 years was used.

As exclusion criteria, we cite other publications that are not classified as scientific articles, such as editorials, and studies with themes that are different from the one of this research.

\section{Study protocol}

The survey was carried out in March of 2016, concomitantly in the five databases (Table 1). It should be emphasized that the selection of the articles was done in pairs, separately, in order to avoid biases in the screening of the articles to be analyzed, and the analyses were independently developed by two reviewers from March to April 2016.
Of the 569 articles found, 117 were excluded because they were repeated within the databases; 53 because they could not be considered scientific articles; and two because the language used was not English, Portuguese, or Spanish. Following this first analysis, and an analysis of the 397 remaining articles, another 105 articles were excluded after their title and abstract were read, because they were not consistent with the research question. Therefore, 292 eligible studies remained to be completely read, according to the figure below (Figure 1).

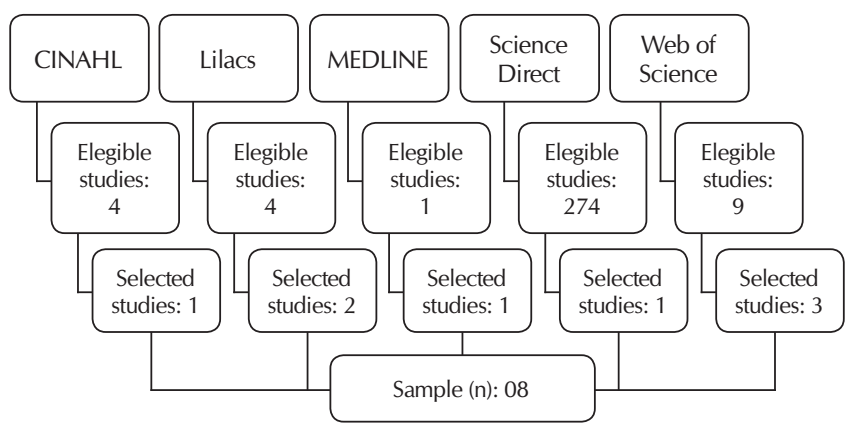

Figure 1 - Flow of selection of eligible articles, according to the databases, Uberaba, Minas Gerais, Brazil, 2016

Articles included in the IR were examined by a constructed and validated instrument ${ }^{(12)}$. Items not pertinent to this research were rejected, and items regarding the identification of the publication and the methodological characteristics were maintained, with the author's agreement, which allowed for the articles' analyses.

Table 1 - Number of references found, according to the crossing of key words, Uberaba, Minas Gerais, Brazil, 2016

\begin{tabular}{|c|c|c|}
\hline Database (total) & Crossing - keywords & Articles found \\
\hline CINAHL (20) & $\begin{array}{l}\text { Knowledge and hypodermoclysis } \\
\text { Nursing and hypodermoclysis } \\
\text { Adult health and hypodermoclysis } \\
\text { Drug administration routes and hypodermoclysis }\end{array}$ & $\begin{array}{c}1 \\
15 \\
4\end{array}$ \\
\hline Lilacs (6) & $\begin{array}{l}\text { Knowledge and hypodermoclysis } \\
\text { Nursing and hypodermoclysis } \\
\text { Adult health and hypodermoclysis } \\
\text { Drug administration routes and hypodermoclysis }\end{array}$ & $\begin{array}{l}1 \\
3 \\
1 \\
1\end{array}$ \\
\hline MEDLINE (4) & $\begin{array}{l}\text { Knowledge and hypodermoclysis } \\
\text { Nursing and hypodermoclysis } \\
\text { Adult health and hypodermoclysis } \\
\text { Drug administration routes and hypodermoclysis }\end{array}$ & $\begin{array}{l}1 \\
3\end{array}$ \\
\hline Science Direct (524) & $\begin{array}{l}\text { Knowledge and hypodermoclysis } \\
\text { Nursing and hypodermoclysis } \\
\text { Adult health and hypodermoclysis } \\
\text { Drug administration routes and hypodermoclysis }\end{array}$ & $\begin{array}{l}146 \\
199 \\
87 \\
92\end{array}$ \\
\hline Web of Science (15) & $\begin{array}{l}\text { Knowledge and hypodermoclysis } \\
\text { Nursing and hypodermoclysis } \\
\text { Adult health and hypodermoclysis } \\
\text { Drug administration routes and hypodermoclysis }\end{array}$ & $\begin{array}{l}2 \\
9 \\
2 \\
2\end{array}$ \\
\hline Total & & 569 \\
\hline
\end{tabular}




\section{Analysis of results and statistics}

The analysis was performed in a descriptive way, according to the data collection instrument, allowing the reader to evaluate the applicability of the elaborated IR, contributing positively to safe nursing practices related to drug and fluid subcutaneous administration in adults, for purposes of decision-making and direction of the clinical practice of the nursing team.

\section{RESULTS}

The eight studies included in the IR (Table 1) are shown below, according to the title, level of evidence, main author's education, language, and journal.

When analyzing the methodological characteristics, we found two $(25 \%)$ literature reviews, one $(12.5 \%)$ case study, and five $(62.5 \%)$ quantitative studies. Regarding the research design, one $(12.5 \%)$ was longitudinal, three $(60 \%)$ were cross-sectional studies, and one $(12.5 \%)$ was near-experimental. Regarding the level of evidence, five (62.5\%) were level VI, three (37.5\%) did not fit the classification, and one (12.5) was level II.

In five $(62.5 \%)$ articles, the main author's education was not mentioned; in the others, there was one $(12.5 \%)$ nurse, one $(12.5 \%)$ physician, and one $(12.5 \%)$ pharmacist. Regarding the language, six (75\%) were in English and the rest (25\%) were in Portuguese.

In addition, with regard to the publication journal, none were repeated, with two (25\%) being Brazilian, and six (75\%) international.

To explain the thematic results found in the articles that composed the sample, it was divided into two categories: nursing knowledge; and nursing team practices. It is worth noting that the article entitled "Hypodermoclysis: the nurse's knowledge in an inpatient unit" was included in both categories, first by approaching both content and practice, and then by the relevance of the results reported in the article in question, despite the small sampling, which could refer to the loss of data for this research.

Chart 1 - Description of the studies included in the integrative review, according to the title, level of evidence, main author's education, language and journal, Uberaba, Minas Gerais, Brazil, 2016

\begin{tabular}{|c|c|c|c|c|c|}
\hline $\mathbf{N}^{0}$ & Title & Level of evidence & $\begin{array}{l}\text { Main author's } \\
\text { education }\end{array}$ & Language & Journal \\
\hline 1 & $\begin{array}{l}\text { A prospective comparison study between } \\
\text { a butterfly needle and a teflon cannula for } \\
\text { subcutaneous narcotic administration }{ }^{(13)}\end{array}$ & II & - & English & $\begin{array}{l}\text { Journal of Pain } \\
\text { and Symptom } \\
\text { Management }\end{array}$ \\
\hline 2 & $\begin{array}{l}\text { Emergency nursing resource: difficult } \\
\text { intravenous access }{ }^{(14)}\end{array}$ & & - & English & $\begin{array}{c}\text { Journal of Emergency } \\
\text { Nursing }\end{array}$ \\
\hline 3 & $\begin{array}{l}\text { Hipodermóclise em pacientes } \\
\text { oncológicos sob cuidados paliativos }{ }^{(3)}\end{array}$ & VI & Nurse & Portuguese & Cogitare Enfermagem \\
\hline 4 & $\begin{array}{l}\text { Hipodermóclise: o conhecimento do } \\
\text { enfermeiro em unidade de internação }\end{array}$ & VI & - & Portuguese & ConScientiae Saúde \\
\hline 5 & $\begin{array}{l}\text { Hypodermoclysis in the care of } \\
\text { older adults: an old solution for new } \\
\text { problems? }\end{array}$ & VI & Physician & English & $\begin{array}{l}\text { Canadian Family } \\
\text { Physician }\end{array}$ \\
\hline 6 & $\begin{array}{l}\text { Hypodermoclysis to treat dehydration: a } \\
\text { review of the evidence }{ }^{(17)}\end{array}$ & - & - & English & Journal compilation \\
\hline 7 & $\begin{array}{l}\text { Subcutaneous administration of drugs } \\
\text { in the elderly: survey of practice and } \\
\text { systematic literature review }{ }^{(18)}\end{array}$ & VI & Pharmacist & English & Palliative Medicine \\
\hline 8 & $\begin{array}{l}\text { Subcutaneous fluid administration and the } \\
\text { hydration o folder people }{ }^{(19)}\end{array}$ & & - & English & $\begin{array}{l}\text { British Journal of } \\
\text { Nursing }\end{array}$ \\
\hline
\end{tabular}


Knowledge by the nursing team

Chart 2 - Description of the studies approaching nursing team knowledge, according to the title, year/country, outline/N, interventions and results found, Uberaba, Minas Gerais, Brazil, 2016

\begin{tabular}{|c|c|c|c|c|}
\hline Title & Year/country & Outline/N & Interventions & Results found \\
\hline $\begin{array}{l}\text { Hypodermoclysis: } \\
\text { nurse's } \\
\text { knowledge in an } \\
\text { inpatient unit }^{(15)}\end{array}$ & $\begin{array}{l}\text { 2010/ } \\
\text { Brazil }\end{array}$ & $\begin{array}{l}\text { Quantitative, non- } \\
\text { experimental, cross- } \\
\text { sectional } / \mathrm{n}=7\end{array}$ & $\begin{array}{l}\text { Questionnaire } \\
\text { application }\end{array}$ & $\begin{array}{l}29 \% \text { of the nurses interviewed had heard of the technique. } \\
\text { One cited the Internet as a source of knowledge, and another an } \\
\text { undergraduate course. } \\
71 \% \text { were unaware of the technique. } \\
100 \% \text { reported not receiving guidance from the institution, } \\
\text { ignoring nursing care. }\end{array}$ \\
\hline $\begin{array}{l}\text { Subcutaneous } \\
\text { fluid } \\
\text { administration } \\
\text { and the hydration } \\
\text { o folder people }\end{array}$ & $\begin{array}{l}\text { 2014/ } \\
\text { England }\end{array}$ & $\begin{array}{l}\text { Literature review/ } \\
\mathrm{n}=13\end{array}$ & & $\begin{array}{l}\text { Advantages: puncture site options; simple insertion; comfort } \\
\text { to the patient; easily usable in home care; reduces net overload. } \\
\text { Disadvantages: limit of 1,500 ml every } 24 \text { hours per puncture } \\
\text { site; local edema; administration of some fluids. } \\
\text { Complications: edema; inflammation/cellulitis; local pain; } \\
\text { hematoma; and occlusion of the device (rare). } \\
\text { Contraindications: rapid fluid replacement; material for access } \\
\text { fixation has to be transparent; sterile technique. }\end{array}$ \\
\hline
\end{tabular}

\section{Nursing team practices}

Chart 3 - Description of articles approaching nursing team practices, according to the title, year/country, outline/N, interventions and results found, Uberaba, Minas Gerais, Brazil, 2016

\begin{tabular}{|c|c|c|c|c|}
\hline Title & Year/country & Outline/N & Interventions & Results found \\
\hline $\begin{array}{l}\text { A prospective } \\
\text { comparison study } \\
\text { between a butterfly } \\
\text { needle and a } \\
\text { teflon cannula } \\
\text { for subcutaneous } \\
\text { narcotic } \\
\text { administration }\end{array}$ & $\begin{array}{l}\text { 1994/ } \\
\text { Canada }\end{array}$ & $\begin{array}{l}\text { Quantitative, near- } \\
\text { experimental/ } \\
\mathrm{n}=20\end{array}$ & $\begin{array}{l}\text { Comparison between } \\
\text { the use of the scalp } \\
\text { no. } 25 \text { with the } \\
\text { combination of a } \\
\text { 26-gauge introducer } \\
\text { needle and an } \\
\text { abocath no. } 24\end{array}$ & $\begin{array}{l}\text { Abocath dwell time was longer than scalp dwell time. } \\
\text { Local reactions: redness; edema; pain; leakage; } \\
\text { manipulation; infection; and cellulitis. } \\
\text { Patients reported no difference in comfort related to the } \\
\text { needle. } \\
\text { Abocath insertion was more difficult. }\end{array}$ \\
\hline $\begin{array}{l}\text { Emergency } \\
\text { nursing resource: } \\
\text { difficult } \\
\text { intravenous } \\
\text { access }^{(14)}\end{array}$ & $\begin{array}{c}\text { 2012/ } \\
\text { United States }\end{array}$ & $\begin{array}{l}\text { Literature Review/ } \\
\mathrm{n}=\text { not informed }\end{array}$ & & $\begin{array}{l}96 \% \text { of nurses considered the procedure easy. } \\
\text { Viability of subcutaneous therapy comparable to that of } \\
\text { the intravenous route. } \\
\text { Time to start hypodermoclysis of } 3.4 \text { minutes and } \\
\text { intravenous route } 6.1 \text { minutes. }\end{array}$ \\
\hline $\begin{array}{l}\text { Hipodermóclise } \\
\text { em pacientes } \\
\text { oncológicos } \\
\text { sob cuidados } \\
\text { paliativos }^{(3)}\end{array}$ & $\begin{array}{l}\text { 2013/ } \\
\text { Brazil }\end{array}$ & $\begin{array}{l}\text { Quantitative, } \\
\text { non-experimental, } \\
\text { longitudinal/ } \\
\mathrm{n}=16\end{array}$ & $\begin{array}{l}\text { Application of } \\
\text { instrument }\end{array}$ & $\begin{array}{l}\text { Of the } 16 \text { patients, } 14 \text { were oncological and two were } \\
\text { under follow-up for pain management. } \\
50 \% \text { of the patients underwent the procedure more than } \\
\text { once. } \\
14 \text { punctures in outpatient care, } 11 \text { at home, and five in } \\
\text { the hospital. } \\
\text { Main site of puncture: infraclavicular region ( } 93.34 \%) \\
\text { Main device: scalp no. } 21(40 \%) \\
\text { Main drug: morphine }(93.75 \%) \\
\text { Exchanges every seven days } \\
\text { Complications: local irritation and hematoma } \\
\text { Main reason for interruption: } 13(81.25 \%) \text { deaths }\end{array}$ \\
\hline
\end{tabular}




\begin{tabular}{|c|c|c|c|c|}
\hline Title & Year/country & Outline/N & Interventions & Results found \\
\hline $\begin{array}{l}\text { Hipodermóclise: } \\
\text { o conhecimento } \\
\text { do enfermeiro } \\
\text { em unidade de } \\
\text { internação(15) }\end{array}$ & $\begin{array}{l}\text { 2010/ } \\
\text { Brazil }\end{array}$ & $\begin{array}{l}\text { Quantitative, } \\
\text { non-experimental, } \\
\text { cross-sectional/ } \\
n=7\end{array}$ & $\begin{array}{l}\text { Questionnaire } \\
\text { application }\end{array}$ & $\begin{array}{l}\text { Technique is not used. } \\
\text { Physicians do not prescribe fluids and drug infusion } \\
\text { subcutaneously. } \\
\text { Resistance in the use of hypodermoclysis in contexts that } \\
\text { do not include palliative care. }\end{array}$ \\
\hline $\begin{array}{l}\text { Hypodermoclysis } \\
\text { in the care of } \\
\text { older adults: an } \\
\text { old solution for } \\
\text { new problems? }{ }^{(16)}\end{array}$ & $\begin{array}{c}\text { 1992/ } \\
\text { Canada }\end{array}$ & Case Study/n=1 & $\begin{array}{l}\text { Case report of } \\
\text { hypodermoclysis use } \\
\text { in the elderly with } \\
\text { Alzheimer's disease }\end{array}$ & $\begin{array}{l}\text { Hypodermoclysis recommended after difficulty in } \\
\text { maintaining intravenous route. } \\
\text { Change of puncture site every two days. } \\
\text { Indication: hydration } \\
\text { Physician: responsible for prescribing and initiating } \\
\text { hypodermoclysis. }\end{array}$ \\
\hline $\begin{array}{l}\text { Hypodermoclysis } \\
\text { to treat } \\
\text { dehydration: a } \\
\text { review of the } \\
\text { evidence }^{(17)}\end{array}$ & $\begin{array}{c}2007 / \\
\text { United Stated }\end{array}$ & $\begin{array}{l}\text { Literature review/ } \\
\mathrm{n}=8\end{array}$ & & $\begin{array}{l}\text { Hypodermoclysis: safe alternative for fluid administration } \\
\text { in adults. } \\
\text { There was no significant difference between efficacy, } \\
\text { duration of puncture site, and discomfort (comparing } \\
\text { subcutaneous and intravenous routes). } \\
\text { Physicians and nurses prefer hypodermoclysis. } \\
\text { Complications: local inflammation; pain; edema; } \\
\text { ecchymosis; and extravasation. } \\
\text { Costs for keeping intravenous route were four times } \\
\text { higher. }\end{array}$ \\
\hline $\begin{array}{l}\text { Subcutaneous } \\
\text { administration } \\
\text { of drugs in the } \\
\text { elderly: survey } \\
\text { of practice } \\
\text { and systematic } \\
\text { literature review }^{(18)}\end{array}$ & $\begin{array}{c}\text { 2005/ } \\
\text { Switzerland }\end{array}$ & $\begin{array}{l}\text { Quantitative, } \\
\text { non-experimental, } \\
\text { cross-sectional/ } \\
\mathrm{n}=79 \text { ( } 27 \text { nurses } \\
\text { and } 52 \text { physicians) }\end{array}$ & $\begin{array}{l}\text { Application of a } \\
\text { questionnaire to } \\
\text { check drugs used } \\
\text { subcutaneously } \\
\text { in the geriatrics } \\
\text { department and } \\
\text { evaluate the } \\
\text { practices }\end{array}$ & $\begin{array}{l}\text { Main drugs: morphine; haloperidol; furosemide; } \\
\text { hydromorphone; glycopyrrolate; ceftriaxone. } \\
\text { Nurses reported administering the medications } \\
\text { several times a day, and physicians thought they were } \\
\text { several times a week. } \\
\text { Puncture change every three days, except five days for } \\
\text { morphine or hydromorphine. } \\
\text { One of the nurses cited mixing the medications in the } \\
\text { syringe (morphine and haloperidol). } \\
11 \% \text { of physicians reported never having checked } \\
\text { which medications were licensed for subcutaneous } \\
\text { administration. } \\
\text { Of the } 34 \text { drugs used, } 13 \text { (38\%) are licensed for } \\
\text { subcutaneous use. }\end{array}$ \\
\hline
\end{tabular}

\section{DISCUSSION}

A number of articles found evidence of the need to extend the research regarding nursing team knowledge and practice, taking the importance of hypodermoclysis in the scenario of care practice into account ${ }^{(20)}$.

The countries that stood out in this study were Brazil and Canada, each with $25 \%$ of the publications. Although the result reveals the prevalence of studies in the English language, which for the academic level of Brazilian students is not a barrier, healthcare professionals, who are expected to be consumers of scientific research, may find limitations due to language when they need evidence to base their decisions on practice.

The two elected categories approached knowledge and nursing care practice, with the former directly impacting the latter and the safe and effective use of this modality of infusion therapy. It is known that the nursing team plays a crucial role in the interaction with patients, and also with the medical team, which is responsible for the prescription of hypodermoclysis, in order to clarify and help in therapy selection ${ }^{(19)}$.

Regarding knowledge about hypodermoclysis, most health professionals ( $71 \%$ ) have never heard of it, and are not aware of the technique, because those who claimed to have knowledge about it did not cite any definition ${ }^{(15)}$.

This lack of knowledge may be associated with a lack of discussion on the subject in schools ${ }^{(15)}$, a fact that needs to be reviewed, because nursing team knowledge allows reflection on the importance of its role in using this method as a therapeutic resource. Theoretical and practical knowledge about SC therapy can minimize mechanical and tissue trauma, provide comfort, and reduce stress and pain from repeated and unsuccessful punctures for the infusion of fluids and drugs ${ }^{(8)}$. 
Thus, it can be noticed that knowledge about hypodermoclysis is still incipient, requiring its dissemination and professional updating ${ }^{(21)}$. There is a need to seek scientific evidence about the use of hypodermoclysis in integral patient care, in order to contribute to a safe care practice ${ }^{(3,22)}$.

Moreover, there is a lack of commitment by health institutions to provide training on SC therapy; thus, professionals do not know how to handle or even direct care with hypodermoclysis, resulting in a lack of adhesion to the technique. A study conducted in Paraná(3) showed that only $0.02 \%$ of the patients used hypodermoclysis at the institution. Therefore, it is necessary to consider that drug administration is one of the care functions performed, most times, by the nursing team; consequently, it is essential to disseminate information to and train this team ${ }^{(8)}$.

Hypodermoclysis is considered a simple, safe, and effective practice for hydroelectrolytic replacement and/or drug therapy in patients who require clinical treatment in a hospital or home setting ${ }^{(1-3,22)}$.

Due to the scarcity of studies and scientific publications that encourage its use, some advantages, even incipient ones, have been presented in order to make the adoption of this practice feasible in health services, including low cost (inexpensive materials when compared to other types of punctures; costs for maintenance of the IV route are about four times greater $\left.{ }^{(17)}\right)$, simplicity of insertion of the peripheral catheter, ease of administration and maintenance, and possibility of early hospital discharge (due to its effectiveness, safety, and ease of home management). It also provides comfort, convenience, and autonomy to the patient, as well as minimal risk of local or systemic complications ${ }^{(1,3,8,22)}$.

Additionally, the technique has the lowest degree of limitation due to the differentiated options of puncture sites (preferably distant from the joints) and low incidence of infection, favoring a greater acceptance by patients, their families, and the health team ${ }^{(6,8,23)}$. Furthermore, it is the best route for safe and effective administration of opioids, with fewer adverse events, by reducing the fluctuation of these drugs' plasma concentrations. Another advantage is that the infusion can be interrupted at any time, with no risk of thrombosis and dysfunctional access ${ }^{(8,22)}$.

Regarding the disadvantages, there is a limitation to the rate of infusion (when this fluid transfer occurs at a rate of $1 \mathrm{ml} /$ minute, absorption occurs without edema ${ }^{(19)}$ and rapid dose adjustment ${ }^{(3,8,15,19-20,22)}$, because absorption by the SC tissue is slower than by the IV pathway for most drugs. Thus, this route is restricted in situations where rapid infusion and replacement with high volumes of fluids are desired, because there is a greater possibility of the emergence of phlogistic signs ${ }^{(1,8)}$.

Furthermore, there is a limitation as to the maximum volume to be infused per puncture site. Some studies mention a maximum volume of $1,000 \mathrm{ml} / 24 \mathrm{~h}$ per puncture site ${ }^{(1,6)}$, others of $1,500 \mathrm{ml} / 24 \mathrm{~h}^{(2,15,18-19)}$. It is emphasized that two puncture sites are allowed ${ }^{(1-3)}$.

Finally, we can mention the intolerance to certain drugs, because there is no development of drugs for specific SC use $^{(8)}$. To date, diazepam, diclofenac, undiluted electrolytes, and phenytoin ${ }^{(1)}$ are incompatible with this route. Other studies also include chlorpromazine ${ }^{(7-8)}$. It is also worth noting that solutions with extreme $\mathrm{pH}(<2$ or $>11)$ present an increased risk of precipitation and local irritation, and preference should be given to isotonic solutions ${ }^{(1)}$.

The adverse effects of administration through this route are rare and preventable. Local reactions may include erythema, hematoma, edema, skin hardening, extravasation, pruritus, pain, inflammation, and infection ${ }^{(8,15)}$.

Risks and systemic complications, such as hyperhydration and cardiac overload, are minimal, because they can be monitored throughout the infusion period, with suspension of use immediately upon detection of any change. Among the rare documented complications, mainly related to drug selection, are granuloma and cellulitis ${ }^{(7-8)}$.

The use of the SC route is indicated for the treatment of patients of any age, for whom the oral (PO) and IV routes are not appropriate or available, or after unsuccessful attempts with other routes of administration ${ }^{(1,8,15,17,23)}$.

Indications for the use of hypodermoclysis include: impossibility of PO ingestion ${ }^{(24)}$; nausea; vomiting; gastrointestinal tract obstruction; and patients with difficult venous access; cases of phlebitis; venous thrombosis; or phlogistic signs. Also, hypodermoclysis offers the patient the possibility of staying at home and of pain and sedation control. However, complications may include dysphagia, confusion, need for terminal sedation, PO opioid intolerance, marked reduction of gastrointestinal absorption, extreme prostration, and unconsciousness ${ }^{(8,15,19)}$.

Absolute contraindications include patient refusal, anasarca, severe thrombocytopenia, and the need for rapid fluid resuscitation (as in severe dehydration and shock) ${ }^{(2)}$. Regarding relative contraindications, there are those associated with coagulation disorders or hemorrhages (from the deficit of absorption associated with peripheral circulation failure due to blood loss); edema; risk of pulmonary congestion; focus of infectious on or near puncture sites; heart failure; patients on peritoneal dialysis; and application to sites with changes in cutaneous integrity, such as those close to operative scars ${ }^{(1,8,19)}$. It should also be noted that, in patients undergoing radiotherapy, the area of choice should be different from that irradiated ${ }^{(8)}$.

The technique consists of the insertion of a needle device in SC tissue, with gauge ranging from 23 to $27 \mathrm{G}$, according to the patient's previous evaluation, the volume to be infused, and the type of solution to be administered ${ }^{(1,3,19,21)}$. Needle no. $13 \times 4.5$ is also cited for intermittent punctures ${ }^{(2,7)}$.

A study conducted in Canada ${ }^{(13)}$ compared the use of abocath and scalp for puncture and concluded that, although the abocath length of stay was higher, practitioners chose to standardize the use of the scalp because of its lower cost and easier puncture.

When the time to initiate the SC infusion is compared with the IV infusion, it is 3.4 minutes and 6.1 minutes, respectively, demonstrating the shortest nursing time to start and maintain the infusion ${ }^{(17)}$.

The sites indicated for puncture are: the deltoid region; anterior chest region (chest region in men and inframammary in women); scapular region (when the patient is agitated or delusional and tends to remove the infusions); abdominal region (considering a circumference around the navel with about four fingers around it); and lateral aspect of the thigh ${ }^{(1,8,22)}$. The flank, infraclavicular, axillary, and anterior or internal aspect of the thigh are also used ${ }^{(3,15)}$. 
Most punctures are performed in the infraclavicular region, followed by the abdominal region ${ }^{(3)}$, perhaps because they are the areas of greatest absorption ${ }^{(8)}$.

Finally, it should be pointed out that intercostal space should be avoided in cachectic patients because of a high risk of pneumothorax, and that sites adjacent to a mastectomy or near a stoma ${ }^{(8)}$ should not be punctured. In addition, direct administration at the site of a tumor, on limbs with lymphedema with previously irradiated skin (blood supply may be reduced), at sites with infection, fissures, or hematomas, and in the abdominal region, when ascites is present ${ }^{(3,8)}$ should also be avoided. In cases of urinary incontinence and/or peripheral vascular insufficiency, the inner face of the thigh should be avoided $^{(15)}$.

Thus, the nurse has the function of evaluating the patient, choosing the appropriate place for puncture in regions with intact skin integrity, and considering the volume of liquid to be administered ${ }^{(3,15,22)}$, preferably to sites that do not interfere with patient movements ${ }^{(8)}$.

Among the drugs currently allowed for SC use are: opioid analgesics (morphine, fentanyl, tramadol, methadone, and hydromorphone); antiemetics (metoclopramine, cyclizine, ondansetron, and dimenhydrin); somatostatin analogue (octreotide); sedatives (midazolam and phenobarbital); antihistamine (promethazine and hydroxyzine); anticholinergics (atropine and scopolamine); corticosteroids (dexamethasone); $\mathrm{H} 2$ blockers (ranitidine and famotidine); diuretics (furosemide); bisphosphonates (clodronate); antibiotics (ampicillin, cefepime, ceftazidime, cefotaxime, ceftriaxone, tobramycin, and garamycin); non-hormonal anti-inflammatory drugs (ketorolac); anesthetics (ketamine); and insulin (regular, fast or simple $)^{(8)}$.

Preferably, for each type of medication, a subcutaneous site is installed. However, when this is not possible, some drugs may be used for the same puncture, according to specific compatibility and saturation and/or local irritation ${ }^{(7)}$. The administration of more than three drugs in the same access is not indicated, because inflammation or infection may occur at the puncture site, leading to the need to exchange the puncture site ${ }^{(8,15)}$.

All medicinal products to be administered through the SC route should be in liquid form and diluted in water for injection, except for ketamine, ondansetron, and octreotide, which must be diluted in saline at $0.9 \%$.

Unlike the devices used in IV punctures, which need to be changed and subjected to new punctures every three days, the abocath remained at the puncture site for an average of 11 days and the scalp for five days ${ }^{(6)}$. It is argued that the SC device remains in direct contact with the adipose tissue and not directly with the bloodstream, so it is considerable that the rotation of the puncture sites occurs in a longer time interval.

There is a divergence regarding length of stay: some references mention, for the scalp, change every three days ${ }^{(15,18)}$, four days ${ }^{(1)}$, five days ${ }^{(2)}$, and seven days ${ }^{(3)}$, while for the abocath, every 11 days ${ }^{(2,6)}$. It is also mentioned that, only for morphine, it is possible to change the device at the most every five days ${ }^{(18)}$.
In a study carried out in Paraná(3), of the 16 patients using hypodermoclysis, the reason for its descontinuation most of the time was patient's death $(81.25 \%)$, followed by the conclusion of the drug treatment $(6.25 \%)$, and patient's refusal to remain with hypodermoclysis $(6.25 \%)$. These results reinforce the applicability of the SC pathway in palliative care ${ }^{(8)}$.

Palliative care emerges in a context in which the number of people with chronic and degenerative diseases increases, requiring improvements in the quality of life through the prevention and relief of suffering, for pain treatment and other physical, spiritual, social, and psychological symptoms. As in this group of patients the access route should be comfortable, not aggressive, and with few side effects, hypodermoclyisis is one of the indicative routes ${ }^{(8)}$. At the same time, although this technique is mainly used in the elderly and in patients undergoing palliative and oncological care $^{(7,15)}$, it can also be used outside of these contexts, such as in patients of other age groups or with other diseases, provided that there is clinical indication and knowledge on the part of the multiprofessional team that attends them ${ }^{(3,15)}$.

Regarding competency, relative to both puncture and fluid administration, both may be delegated by the nurse to the members of the nursing team, provided that the professionals are trained, qualified, and able for such procedures ${ }^{(25)}$. Even with such a report, a study shows that $100 \%$ of the team reported ignoring nursing care related to this practice, stating that they did not receive guidance from the institution. The nursing team, together with other health professionals, should build and use care protocols that will guide patient care, thus encouraging the use of the technique ${ }^{(3,22)}$.

At the same time that the technique can be carried out by the members of the nursing team, its prescription is a medical assignment, which also demands training from these professionals. A study conducted in Switzerland(18) revealed that $11 \%$ of physicians reported never having checked which medications were currently licensed for SC, and that, of the 34 drugs used, only 13 (38\%) were licensed to be administered through this route. It was also noticed that there was disagreement between the medical and nursing staff about the preparation and administration of the fluids.

Thus, it should be emphasized that professionals should base their clinical practice on the best scientific evidence, improving their knowledge related to this technique, indications and contraindications, therapeutic viability, favorable physiological conditions, devices, solutions and medications allowed, in order to reduce the occurrence of possible adverse events ${ }^{(21)}$. The use of the SC route can be considered a safe practice, without serious complications, of handling and simple maintenance, when the technical procedures and the compatibilities between the solutions are observed ${ }^{(7)}$.

\section{Study limitations}

The limitations of this research were the absence of studies with a high level of evidence as well as the low scientific production, especially the Brazilian one, on the subject, which supports the recommendation on adherence to this practice and its use, still incipient in some health services. 


\section{Contributions to the nursing area}

The knowledge about hypodermoclysis, as well as its practical applicability, aims to contribute positively to the adhesion to the technique, when indicated, mainly considering its benefits for the patient, the professional, and the health institution.

\section{CONCLUSION}

In this IR, it was possible to gather and synthesize knowledge and procedures about the administration of drugs and fluids through the SC route in the adult. Therefore, there is some knowledge in it to clarify and encourage the practice and development of future research that may determine the applicability and use of hypodermoclysis because, as noted by the limited literature found, there is a lack of studies on this topic, and more investment in research is required.

Even given the multiple applicable clinical advantages, this route still remains underused, and there is an urgent need for more clinical studies to promote decision-making and to guide clinical practice among professionals. The study allows a reflection on the practice of hypodermoclysis in the routine of the nursing team, and what the factors and/or barriers that justify its disuse are, even when it presents itself as a safe, well-tolerated, and low-cost procedure.

\section{REFERENCES}

1. Brasil. Ministério da Saúde. Terapia subcutânea no câncer avançado[Internet]. Rio de Janeiro: Ministério da Saúde; 2009[cited 2016 Mar 09]. Available from: http://bvsms.saude.gov.br/bvs/publicacoes/inca/Terapia subcutanea.pdf

2. Sociedade Brasileira de Geriatria e Gerontologia. Associação Nacional de Cuidados Paliativos. O uso da via subcutânea em geriatria e cuidados paliativos[Internet]. Rio de Janeiro: SBGG, 2016[cited 2016 Mar 09];56p. Available from: http://sbgg.org.br/ wp-content/uploads/2016/06/uso-da-via-subcutanea-geriatria-cuidados-paliativos.pdf

3. Justino ET, Tuoto FS, Kalinke LP, Mantovani MF. Hipodermóclise em pacientes oncológicos sob cuidados paliativos. Cogitare Enfermagem[Internet]. 2013 [cited 2016 Mar 09];18(1):84-9. Available from: http://revistas.ufpr.br/cogitare/article/ view/31307/20018

4. Barua P, Bhowmick BK. Hypodermoclysis: a victim of historical prejudice. Age Ageing[Internet]. 2005[cited 2016 May 05];34:21517. Available from: http://ageing.oxfordjournals.org/content/34/3/215.long.

5. Da Polian Zironde ES, Marzenini NL, Soler VM. Hipodermóclise: redescoberta da via subcutânea no tratamento de indivíduos vulneráveis. CuidArte Enferm[Internet]. 2014 [cited 2016 Mar 09];8(1):55-61. Available from: http://fundacaopadrealbino.org.br/ facfipa/ner/pdf/cuidarte_enfermagem_v8_n1_jan_jun_2014.pdf.

6. Sasson M, Schvartzman P. Hypodermoclysis: an alternative infusion technique. Am Fam Physician. 2001 [cited 2016 May 05];64(9):1575-78. Available from: http://www.aafp.org/afp/2001/1101/p1575.pdf

7. Girondi JBR, Waterkemper R. A utilização da via subcutânea como alternativa para o tratamento medicamentoso e hidratação do paciente com câncer. Rev. Min. Enf[Internet]. 2005 [cited 2016 Mar 09];9(4):348-54. Available from: http://www.reme.org.br/ artigo/detalhes/483

8. Vidal FKG, Oselame GB, Neves EB, Oliveira E. Hipodermóclise: revisão sistemática da literatura. Rev Atenc Saúde[Internet]. 2015 [cited 2015 Nov 30];13:61-9. Available from: http://seer.uscs.edu.br/index.php/revista_ciencias_saude/article/view/2953/1784

9. Bruno VG. Hipodermóclise: revisão de literatura para auxiliar a prática clínica. Einstein. 2015[cited 2016 Mar 26];(13):122-28. Available from: http://www.scielo.br/pdf/eins/2015nahead/pt_1679-4508-eins-1679-45082015RW2572.pdf

10. Mendes KDS, Silveira RCCP, Galvão MC. Revisão integrativa: método de pesquisa para a incorporação de evidências na saúde e na enfermagem. Texto Contexto Enferm[Internet]. 2008 [cited 2015 Nov 30];17(4):758-64. Available from: http://www.scielo.br/ pdf/tce/v17n4/18.pdf

11. Ganong, LH. Integrative revies of Nursing Research. Res Nurs Health[Internet]. 1987 [cited 2016 May 05];10(1):1-11. Available from: http://www.ncbi.nlm.nih.gov/pubmed/3644366

12. Nicolussi AC. Qualidade de vida de pacientes com câncer de cólon e reto: revisão integrativa da literatura. [Dissertação]. Ribeirão Preto: Escola de Enfermagem de Ribeirão Preto; 2008[cited 2016 May 05]. 209 f. Available from: http://www.teses.usp.br/teses/ disponiveis/22/22132/tde-03092008-111111/pt-br.php

13. Macnillan K, Bruera E, Kuehn N, Selmser P, Macnillan A. A prospective comparison study between a butterfly needle and a teflon cannula for subcutaneous narcotic administration. J Pain and Symptom Manage [Internet]. 1994 [cited 2016 Mar 09];9(2):82-4. Available from: http://www.sciencedirect.com/science/article/pii/0885392494901600

14. Crowley M, Proehl J, Barnason S, Leviner S, Lindauer C, Naccarato $M$ et al. Emergency nursing resoure: difficult intravenous access. J Emerg Nurs[Internet]. 2012 [cited 2015 Nov 30];38(4):335-43. Available from: http://www.jenonline.org/article/ S0099-1767(12)00226-7/pdf

15. Takaki CYI, Klein GFS. Hipodermóclise: o conhecimento do enfermeiro em unidade de internação. ConScientiae Saúde[Internet]. 2010 [cited 2016 Mar 09];9(3):486-96. Available from: http://www.redalyc.org/pdf/929/92915180020.pdf 
16. Molloy DW, Cunje A. Hypodermoclysis in the care of older adults: an old solution for new problems? Can Fam Physician[Internet]. 1992 [cited 2015 Nov 30];38:2038-43. Available from: http://www.ncbi.nlm.nih.gov/pmc/articles/PMC2145510/pdf/canfamphys00127-0088. pdf

17. Remington R, Hultman T. Hypodermoclysis to treat dehydration: a review of the evidence. J Am Geriat Soc[Internet]. 2007 [cited 2016 Mar 09];55(12):2051-55. Available from: https://www.ncbi.nlm.nih.gov/pubmed/17971137

18. Fonzo-Christe C, Vukasovic C, Wasilewski-Rasca Af, Bonnarbry P. Subcutaneous administration of drugs in the elderly: survey of practice and systematic literature review. Palliat Med[Internet]. 2005 [cited 2016 Mar 09];19(3):208-19. Available from: http:// pmj.sagepub.com/content/19/3/208.short

19. Gabriel J. Subcutaneos fluid administration and the hydration of older people. Br J Nurs. 2014 [cited 2015 Nov 30];23(suppl 14):S10-4. Available from: http://www.ncbi.nlm.nih.gov/pubmed/25062366

20. Braz CL, Pereira RCC, Costa JM. Administração de medicamentos por hipodermóclise: uma revisão da literatura. Rev Bras Farm Hosp Serv Saúde São Paulo[Internet]. 2015 [cited 2016 May 05];6(1):6-12. Available from: http://www.sbrafh.org.br/rbfhss/public/ artigos/2015060102000656BR.pdf

21. Khan M, Younger G. Promoting safe administration of subcutaneous infusions. Nurs Stand[Internet]. 2007 [cited 2016 Mar 26];11-17;21(31):50-6. Available from: http://journals.rcni.com/doi/pdfplus/10.7748/ns2007.04.21.31.50.c4545.

22. Pontalti G, Rodrigues ESA, Firmino F, Fábris M, Stein MR, Longaray VK. Via subcutânea: segunda opção em cuidados paliativos. Revista HCPA[Internet]. 2012 [cited 2016 Apr 09];32(2):199-207. Available from: http://seer.ufrgs.br/hcpa/article/ viewFile/26270/19181

23. Spandorfer PR. Subcutaneous rehydration: updating a traditional technique. Pediatr Emerg Care. 2011 [cited 2016 Mar 26];27(3):230-36. Available from: http://journals.Iww.com/pec-online/Abstract/2011/03000/Subcutaneous_Rehydration_Updating_a_Traditional.19.aspx.

24. Ker K, Tansley G, Beecher D, Perner A, Shakur H, Harris T et al. Comparison of routes for achieving parenteral access with a focus on the management of patients with Ebola virus disease. Cochrane Database of Systematic Reviews[Internet]. 2015 [cited 2016 Jun 16];(2). Available from: http://www.ncbi.nlm.nih.gov/pmc/articles/PMC4455225/pdf/CD011386-0001.pdf.

25. Brasil. Conselho Regional de Enfermagem São Paulo. Punção e administração de fluidos na hipodermóclise[Internet]. Parecer Coren SP 031/2014. [cited 2016 Jun 02]. Available from: http://portal.coren-sp.gov.br/sites/default/files/parecer_coren_sp_2014_031.pdf. 